\title{
Dynamics of structure and abundance of night migratory community in the littoral zone of lake Baikal
}

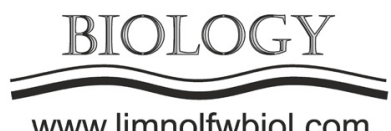

www.limnolfwbiol.com

\author{
Karnaukhov D.Yu.*, Biritskaya S.A., Dolinskaya E.M., Teplykh M.A., \\ Ermolaeva Ya.K., Pushnica V.A., Silow E.A.
}

Institute of Biology, Irkutsk State University, Lenin str., 3, Irkutsk, 664025, Russia

\begin{abstract}
Monthly observations of night migratory community of the hydrobionts in the southern part of Lake Baikal near the Angara river head were conducted between November 2017 and January 2018. Distinctions in structure and abundance of different hydrobiont groups depending on the month of the observation were shown. Thus, the pelagic amphipod Macrohectopus branickii was present as a part of night migratory complex only on November 2017 and the peak of benthic amphipod numbers was observed on December 2017. The decrease of migration activity during the period was probably associated with a lowering of water temperature. Key words: Baikal, migratory community, amphipods, light pollution.
\end{abstract}

Keywords: Baikal, migratory community, amphipods, light pollution

\section{Introduction}

Phenomenon of daily vertical migrations of hydrobionts widely occurs in a number of large water bodies and Lake Baikal is not an exception (Misharin et al., 2006; Labay and Labay, 2014; Takhteev and Didorenko, 2015; Karnaukhov et al., 2016a; 2016b). It is characterized by the fact that benthic amphipods in the littoral zone float into upper water layers at night and they are the part of so-called "night migratory complex" (Karnaukhov et al., 2016a; 2016b; Karnaukhov et al., 2017). Currently, night migratory community is strongly investigated. To date there are few hypothesizes explaining the migratory behavior of benthic amphipods and its causes. Pelagic amphipod Macrohectopus branickii (Dyb.), Cottoidei fish and whitefish are the part of night migratory community in Lake Baikal besides benthic amphipods. Also, lower crustaceans are the active part of such migrations. The purpose of this study is to identify the characteristics of migration behavior of hydrobionts in conditions of light pollution.

\section{Materials and methods}

The study of the community was conducted in the Baikal littoral zone ( $2 \mathrm{~m}$ ) off the village Listvyanka near the Angara river head from November 2017 to January 2018. The observations were made once a month and started at 21:00 o'clock. The video recording system with attached thermologger and plankton net were used for the study. Also, another thermologger was placed on the bottom of the investigation site during whole period of the study. The video system was initially put on the bottom for 15 minutes, then it was raised to the water surface where it was recording for another 5 minutes. The obtained videos were investigated in the laboratory: every 5 seconds video was stopped and all organisms on the screen were counted and the data were collected into the tables.

\section{Results and discussion}

Temperature data obtained with thermologger are presented on the graph (Fig. 1). Observations conducted from November 2017 to January 2018 provided the following data: abundance of benthic and pelagic amphipods in the community was different, moreover, $M$. branickii was seen only during the first observation in November 2017 (Fig. 2). The maximum number of benthic amphipods in November 2017 was 8 specimens per freeze frame, while in December the maximum number increased to 27 specimens per freeze frame. In January 2018 the maximum number was only 5 specimens per freeze frame. The maximum number of the pelagic amphipod M. branickii in November was 5 specimens per freeze frame and for Cottoidei fish, that were recorded as a part of the community only in November, was 2 specimens per freeze frame (Fig. 2). 


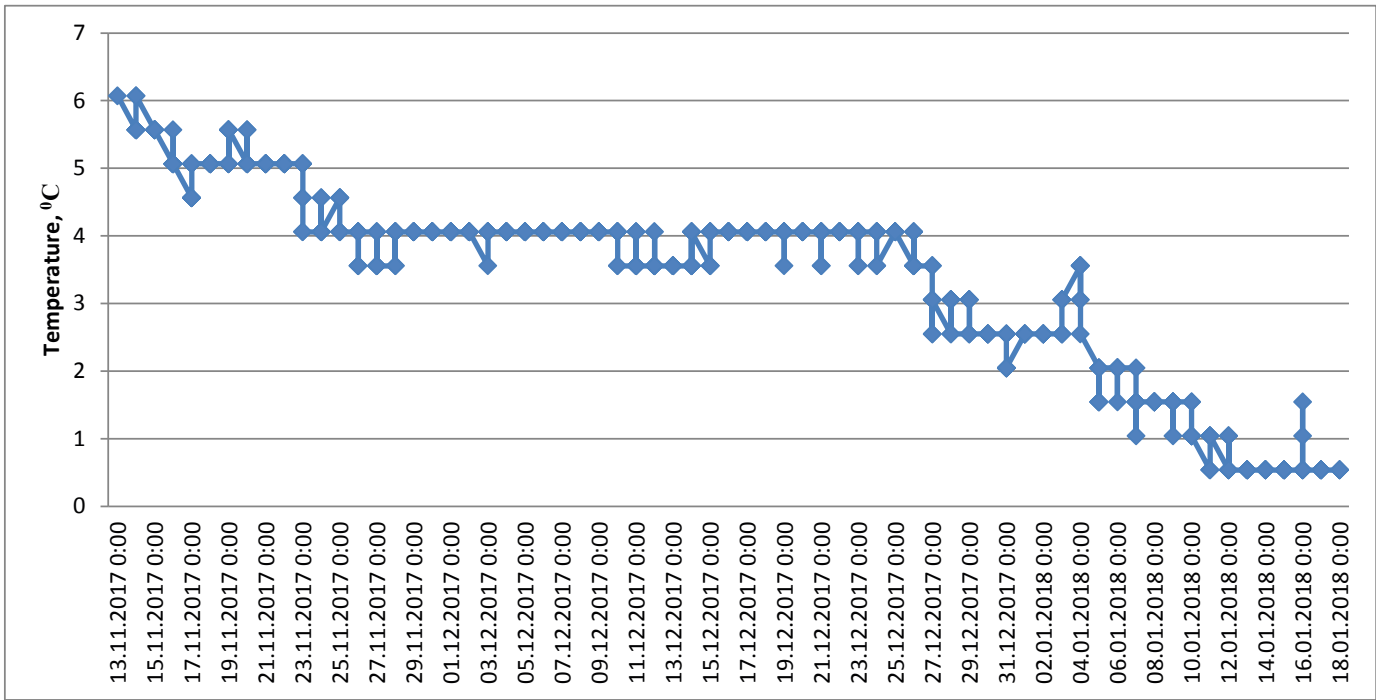

Fig.1. Water temperature change in the investigated site of Lake Baikal.

\section{Conclusion}

A decrease in the benthic amphipod abundance was probably caused by a decrease in water temperature and freeze-up of Baikal (despite the fact that in the vicinity of the observation site the freeze-up did not occur). Probably, the lack of Cottoidei fish and $M$. branickii in the community was also related with the a fore mentioned fact. Also, the lack of $M$. branickii may have been conditioned by the fact that the species reacts differently to the artificial light.

\section{Acknowledgements}

The study was supported by the Project of Russian Ministry of Science and Education N FZZE-2020-0026.

\section{References}

Karnaukhov D.Yu., Takhteev V.V., Misharin A.S. 2016a. Structural features of the nocturnal migratory complex of hydrobionts in different parts of Baikal Lake. Izvestiya Irkutskogo Gosudarstvennogo Universiteta. Seriya "Biologiya. Ekologiya" [The Bulletin of Irkutsk State University. Series "Biology. Ecology"] 18: 87-98. (in Russian)
Karnaukhov D.Yu., Bedulina D.S., Kaus A. et al. 2016b. Behaviour of Lake Baikal amphipods as a part of the night migratory complex in the Kluevka settlement region (South-Eastern Baikal). Crustaceana 89: 419-430. DOI: 10.1163/15685403-00003530

Karnaukhov D.Yu., Dolinskaya E.M., Silow E.A. 2017. Nablyudeniya za pelagicheskoy amfipodoy Macrohectopus branickii (Dyb.) na litoral'noy tochke v ozere Baykal v raznyye sezony goda. In: International Conference "Lomonosov's Reading in Altai: Fundamental Problems of Science and Education", pp. 1393-1395. (in Russian)

Labay V.S., Labay S.V. 2014. Daily vertical migrations of malacostraca (crustacean) in lagoon lake Ptich ye (southern Sakhalin). Chteniya Pamyati Vladimira Yakovlevicha Levanidova [Vladimir Ya. Levanidov's Biennial Memorial Meetings] 6: 369-379. (in Russian)

Misharin A.S., Takhteev V.V., Levashkevich A.M. 2006. The comparative characteristic of night migratory activity of hydrobionts on the various sites in the littoral zone of Lake Baikal. In: Gidrobiologiya vodoyemov yuga Vostochnoy Sibiri [Hydrobiology of the basins in south of East Siberia]. Irkutsk, pp. 52-66. (in Russian)

Takhteev V.V., Didorenko S.I. 2015. Fauna i ekologiya bokoplavov ozera Baykal: uchebnoye posobiye [Fauna and ecology of amphipods of Lake Baikal: a training manual]. Irkutsk: V.B. Sochava Institute of Geography SB RAS Publishing House. (in Russian)

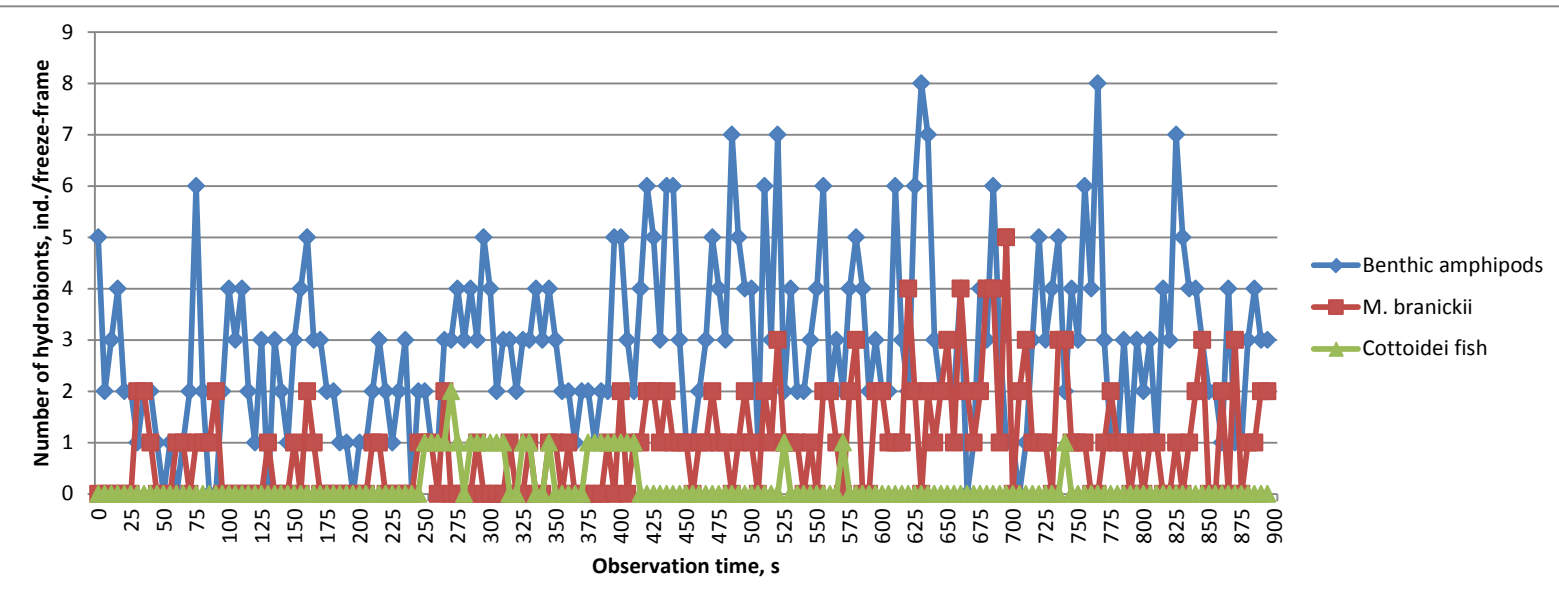

Fig.2. Migratory community abundance near the bottom of the investigated site of Lake Baikal. 